\title{
ARCHITECTURE AND MUSIC/SOUND: POINTS OF MEETING, NETWORKING, INTERACTIONS
}

\section{A B S T R A C T}

This paper is devoted to perceiving the relationship between music and architecture, namely, the discourses which interpret, research, value these two practices in the context of their mutual networking. In that respect it is possible to set aside several problem strongholds which will make the focus of this paper, and which concern: the history of forming and evolution of discourse on the inter-relationship of these two practices; modernist, avant-garde and postmodernist problematization of music and architecture; theories of the artists as a field of music and architecture networking; the interaction of music and architecture on the technical and formal level; spatiality of sound, i.e., sound/music propagation in space and the emergence of the new art concepts based on this principle (sound architecture, aural architecture, sound art). 
Music as sound/tone art organized in time and architecture as art of building, namely planning, shaping and articulating of space/in space are the medium, conceptually and functionally differentiated disciplines among which it is yet possible to establish certain relations and analogies. This has been confirmed by various theories in the focus of which is exactly the research of the relationship between music and architecture, namely sound and space. The theories on conceptualization of this relationship are various discursive models (philosophical, aesthetic, poetic, technical, formal, social, humanist and cultural) which describe, interpret, research and value these two practices in the context of their mutual networking, symbiosis and action. Among the theoretical texts it is possible to single out several thematic and problem concerned stronghold related to: history of forming and evolution of discourse on the relationship of these two practices; modernist, avant-garde and postmodernist problematization of music and architecture; theories of the artists as a field of music and architecture networking; the interaction of music and architecture on the technical and formal level; spatiality of sound, i.e., sound/music propagation in space and the emergence of the new art concepts based on this principle (sound architecture, aural architecture, sound art).

\section{SYSTEMATIZATION OF KNOWLEDGE ON THE RELATIONSHIP BETWEEN MUSIC AND ARCHITECTURE}

Since the ancient times the discourse on the relationship between these two practices has developed first in the field of the formal/natural sciences, then humanist and social sciences, namely, in the field of discourse of the theory of music/musicology and theory of architecture. Until the modern times, the relationship between music and architecture has not been set as a reciprocal one, but as a unidirectional one, in the direction of the effect of music upon architecture, to have later on this relationship become an interactive one. The prerequisites for forming the theoretical talk on relationships between music and architecture are found in the field of the ancient Greek culture, first in the specific interpretation of the notion techne which comprised a wide spectrum of activities, arts, skills, among which there were also those presently characterized as music (e.g. lyre or flute playing) or architecture (house building). ${ }^{1}$ Besides the common starting point/origin, music and architecture were also connected by the belief that these two disciplines dwelled on the same organizational principle - the ordered structures determined by numerical relations. Pythagoras (6th century BC) Theorem according to which music, namely the relation between the consonances, is based on numerical proportions, derived on the basis of the calculations of the length of kithara wires, ${ }^{2}$ served as a universal 
method for explanation of all natural phenomena, functioning of the world and the entire universe, and thus also for the process of designing and building. ${ }^{3}$ The system of proportions as the means of achievement of the harmony of spheres remained paradigmatic until the end of the Renaissance, owing to the writing and influence of Plato and Neo-Platonists. To this model Plato adds one more function: harmony and proportion are the denominators of the beautiful; objectively beautiful, therefore, is that which rests on proportion. ${ }^{4}$ More concrete theoretical problematization of the relationship between music and architecture is laid down by the Roman builder and the first significant theoretician of architecture, Vitruvius, in his tractate De arhitectura libri dacem (1st century BC). Guided by the standpoint that building and space organization must be assisted with knowledge, achievements and principles from other disciplines, he emphasizes also the importance of the knowledge of music regularities for the education of architects and in general for designing and building. Vitruvius gives a word: „Let him (an architect, BS) be educated, skillful with the pencil, instructed in geometry, know much history, have followed the philosophers with attention, understand music, have some knowledge of medicine, know the opinions of the jurists, and be acquainted with astronomy and the theory of the heavens". ${ }^{5}$ The Medieval theoreticians, such as Boethius ( $6^{\text {th }}$ century AD), formally position music and architecture as opposite categories. Whereas music was systemized as practice related to present sciences (along with arithmetic, geometry and astronomy it formed the quadrivium of liberal arts - artes liberales), architecture was identified as craftsmanship discipline, i.e. practical or mechanical art (artes mechanicae artes vulgares) whose final outcome was determined by divine action. ${ }^{6}$ Yet, the principles of numerical rationalization and proportion which condition the achievement of harmony still exist as paradigms, i.e. act in interaction with theological metaphysical discourse. Thomas Aquinas thus speaks about the visual harmony denoting the divine presence, and which actually originates from the regularities of music. ${ }^{7}$ Since the Renaissance architects have inherited the classic Roman principles, the idea on harmony of form and mathematical proportions as measures of beautiful remains a constant. Leon Battista Alberti in his tractate on architecture De Re Aedificatoria (1452-85) accentuates the connection between the harmonious relations and dimensions in architecture, pointing out: "We shall therefore borrow all our Rules for the Finishing our Proportions, from the Musicians, who are the greatest Masters of this Sort of Numbers, and from those Things wherein Nature shows herself most excellent and complete". ${ }^{8} \mathrm{He}$ also empirically puts forward this statement by designing the facade of the Florentine palace, Palazzo Rucellai (1455) exactly according to the regularities of music. Such standpoint is also taken by Andrea 
Palladio, who, in his tractate I Quattro Libri dell'Architettura (1570) states that perfect proportions are achieved by the principles of arithmetic, geometry and harmonious regularities. ${ }^{9}$ The belief that the harmony of the Universe unites architecture and music becomes the subject of critique with the more intensive development of modern science. In mid-seventeenth century, architecture and music became freed from the cosmological meaning, and the new theories and experimental techniques enabled the scientist to research the physical dimensions of sound and space in more detailed manner. At that time the theoretical discourse on music and architecture was formed around music and special branch of this field - architectural acoustic, and the first applications are found in the tractates on theater from the seventeenth century (the study by Carini Motta on design of theater and stage, titled Trattato sopra la struttura de' teatri e scene, 1676). The French architect, Pierre Patte, was among the first ones who strived to elaborate the issues of acoustics and architecture by scientific methods in his study Essai sur l'architecture théâtrale (1782), although this discipline will start with its true development only at the beginning of the twentieth century.

The mimetic basis of the discourse on music and architecture in the nineteenth century was further critically considered and redefined. One of the first interpretations on this topic was presented by Friedrich Schelling (Philosopie der Kunst, 1859). Schelling says: "Music, to which architecture corresponds among the various forms of the plastic arts, is freed from the requirement of portraying actual forms or figures ... [It is] separated from matter. Architecture, however ... if it is music, then it is frozen music". ${ }^{10}$ Neither music, nor architecture, therefore, according to Schelling, negates the concept of mimesis, which makes them analogous; that is why Schelling calls architecture also as „music of plastic arts". ${ }^{11}$ Hippolyte Taine, (Philosophie du l'art, 1868) also describes architecture as production of harmonious entity the sample of which cannot be found in nature, which means that architecture, as well as music, are not determined by mimesis of real objects. ${ }^{12}$

\section{THEORIES OF THE ARTISTS}

Until the twentieth century the discourses of music and architecture networked around technical and formal issues, to have, at the beginning of the new millennium, the common ideological endeavors placed in the limelight and which branched from both directions. The modernist discourse on these relations was first created by the artists in the form of theoretical and auto poetic statements, however, also by the philosophers, sociologists and others, first 
those guided by the avant-garde tendencies directed towards deconstruction of the canons and forming of the new art order. For the representatives of futurism that meant propagating the ,aesthetics of machines" which became the model of the New music, i.e. the art of noise (Luigi Russolo, L'arte dei rumori, 1913) and the New Architecture (Antonio Sant'Elia/, the manifest on the occasion of the project Città Nuova, 1914). Antonio Sant'Elia rejects the classic, monumental, ornamental architecture and advocates for the simplicity, personified in the materials like concrete, iron, glass ${ }^{13}$ analogously to that, Russolo believes that everyday sounds, the sounds of industrialization and machines must 'enter' the music and be treated as music material. ${ }^{14}$ The industrialization of the artistic life was reflected also in the field of French purism of the 20s (Le Corbusier) and the constructivist phase of the Bauhaus architecture (Walter Gropius). Le Corbusier's thesis that the "house is machine for living", namely the vision about the "house-machine" which will be the characteristics of mass production, becomes the guiding idea of the architects, and the analogues to this standpoint are found also in music (Vers une architecture, 1923). The effects of industrialization and urbanization have directed the process of 'liberation' and expansion of the acoustic fundus, which, for example, can be heard in the works of the composer Edgard Varèse (Amériques, 1921) or George Antheil (Ballet Mécanique, 1924), in which these authors use the concrete objects as sources of the sound (sirens, aircraft propellers and similar). Purism of Le Corbusier, based on negating decorativeness and return to clear forms finds its counterpart in the aesthetics of simplicity of Erik Satie, who also advocated for the simple music structures and means for the purpose of creating unpretentious everyday music, which should become a part of the living environment, same as furniture (the concept of the music of furniture/musique d'amebleument). ${ }^{15}$ Le Corbusier, himself, even emphasizes the analogies between music and architecture: „Music is time and space, like architecture. Music and architecture depend on measurements taken". ${ }^{16}$ In his poetics it is also possible to find the concrete references to music: music instruments, first of all pianos, are seen in some of the sketches of the interior space; for creation of a series of wallpaper for the company Salubra he created the method of colors selection under the name "colored keyboards", and according to the principle of the keys on the keyboards. Also, the Notre Dame-du-Haut church in Ronchamp he describes using the terminology of sound. He characterizes this building as ,acoustic ambience” which represents the visual echo of the acoustic environment in which it is situated. Le Corbusier names this as "the fourth dimension of architecture", i.e. acoustic space (espace acoustique), the concept which reconsiders how the building 'echoes' in space and resonates with the environment. ${ }^{17}$ His concept 
of modulor (1950) as the model for establishing proportions according to the principles of golden section and proportions of the human figure can also be compared to the music techniques. Certain analysts believe that the composer Béla Bartók was guided by the principle of the golden section and Fibonacci sequence when composing (e.g. in the work Music for Strings, Percussion and Celesta, 1936). Although they did not offer theoretical explications on the relationship between music and architecture, the Bauhaus artists left behind a significant contribution in the field of designing of the concert halls (Hans Poelzig, Salzburg Festpielhaus, 1920-22).

A unique example and theoretical speech on the mutual influence of architecture and music, the influence of architecture and architectural method on composing process, as well as on the music itself, namely the influence of music upon designing as a creative act, has been presented by the composer and architect Iannis Xenakis. The example of formally-technical process of relating is represented by Xenakis' system for composing by means of drawings, namely in the manner of creation of architectural sketch, and by using the hardware device incorporating ten drawing board connected to the computer (UPIC/Unité Polyagogique Informatique du CEMAM, 1977). Other Xenakis' projects which demonstrate the ideas of connection between music and architecture are: the facade of the La Tourette monastery based on the concept of the ,area of the music glass" built according to the logic of the music rhythm which imposes to the eye the diachronic, music perception; the composition Metastazis (1953-4) based on the bundles of straight lines represented by glissandos forming sound blocks, as well as on the principle of Le Corbusier's modulor; the construction of the Philips Pavilion (1958, EXPO '58), after Le Corbusier's sketches, partially originated after the model of the composition Metastazis. ${ }^{18}$ Pavilion was conceived as an installation space, for multimedia presentation, with: 350 speakers organized in „sound tracks" and clusters, by illumination (five different light effects - the colored light; the images of the Sun, the Moon and the stars on the ceiling; two figures,, female sculpture and abstract metal sculpture, emitting red and green light; two large screens on which images and film were projected; accentuating the screen borders by light rays), film projections and music. The music background consisted of two pieces: Concrete PH by Xenakis and Poème électronique by Edgar Varèse. Varèse's piece represented the music counterpart of the pavilion and was played from three tapes via speakers arranged along certain orbits. ${ }^{19}$ Here one can speak about spatialization of music and the problem of interaction between sound and space. Xanakis empirically problematizes this issue in the piece Polytopes (1967-88) in which he achieves the vision of dynamic and 
spatial multimedia art based on the use of the colored light and electronic music in space, and theoretically explains it in the text Formalized music (1971) in which he explains how music and architecture can 'collaborate' towards the ultimate goal - creation of the total listening experience.

More intensive interaction between architecture and music happened in the early $80 \mathrm{~s}$, and one of the examples is the imaginary city of Peter Cook called Bloch city. It concerns the project of using the score of the violin concert of the composer Ernest Bloch as a model for urban and architectural planning. Thus the music symbols become buildings, streets, walls, and the melody, rhythm and harmony condition the concept of space shaping. That means, according to the author, that music continuity and spatial continuity of architecture dwell on the same principles.$^{20}$ Steven Hall also starts from the music score as a model when working on the project Stretto House (1989-1991, Texas). He uses the recording of the composition the Music for strings, percussion and celesta by Béla Bartók. This composition was created by using stretto technique which the architect strived to simulate when designing this house, and was guided by the principle of golden section, the pivotal/central technique of Bartók's composition. Unlike these authors, the architects Bernard Tchumi and Daniel Libeskind do not use the scores as models, but establish the analogies with music, namely find the inspiration in concrete music practices. Tchumi's project Parc de la Villette (1983), the first example of the deconstructivist architecture, according to the author's explanations, functions as the achievement of the minimalistic music - there is no rhythm, synthesis and order here, however, the visual effect is not disturbing, but acts as if it is similar to the manner in which different rhythms are presented one opposite another in the music of minimalism. ${ }^{21}$ The conceptual aspects of the opera Moses and Aaron by Arnold Schoenberg have encouraged Libeskind when designing the Jewish Museum in Berlin (1999). ${ }^{22}$ Disharmony as a new order is the model which Libeskind takes over from Schoenberg, and he was inspired also by the thematic dedicated to the Jewish Pogrom. Libeskind's discourse on architecture and music rests on emphasizing the analogies: both disciplines require maximum discipline and engagement, both disciplines are exact and precise, for both it is important the time flow and use of the recordings/drawings as starting points of creation. ${ }^{23}$

\section{MUSIC / SOUND IN SPACE}

Although, without any doubt, music is a temporal art, space, i.e. the perception of space is also an essential part of music experience. In other words, music is the sound organized in time and space. Even though this position has become prominent since the mid-twentieth century, it is undisputed that music has 
always comprised a spatial component as well, which related to the space of performing, locating the source of the sound, positioning of the body of the listener. ${ }^{24}$ It was already since the end of the sixteenth century and further that examples were found in which the experience of space was the aspect affecting the creative process and perception. Space thus conditions (1) the manner of composing (The Venetian polychoral style /cori spezzati/was developed under the influence of the very organization of space, of St. Mark's Cathedral, where, due to the existence of the two separated booths, the choirs had to sing in the antiphon manner, and not simultaneously); (2) perception (in order for the sound to 'propagate' better Hector Berlioz wished to divide the orchestra into four groups, and position each of them in the four corners of the hall, while the classic orchestra would be in the center, and after him that idea was applied also by other composers, such as Gustav Mahler or Charles Ives (3) entire poetic and creative result (in the context of the development of Gesamtkunstwerk Richard Vagner develops the idea on special theater, of peculiar architectural and acoustic qualities, in which his pieces will be played). ${ }^{25}$ With the development of electronic music, space acquires a constitutive role in forming and presentation of music discourse and work. One of the examples is found in the field of concrete music (musique concrète) by Pierre Schaeffer, for which distribution the potentiometer of space (potentiomètre d'espace) was conceived, the device controlling the orbit of the sound between the speakers. The idea of spatial music is particularly elaborated by Karlheinz Stockhausen, pointing out that "I knew that the synthesis of sound and space music would be the most important aspect of the music of our time and of the future" (the text "Music in Space"/"Music in Raum", 1959/61). ${ }^{26}$ For presentation of such type of music Stockhausen proposes also the new concept of the concert space which should be of spherical shape, equipped with speakers, with a platform in center for the audience, or a greater number of mobile platforms, at different heights, which would enable to feel 'coming' of the sound from different directions. ${ }^{27}$ This spherical pavilion should have been the equivalent to the art gallery, and filled with continuous programs of the electronic music which would be available, just like in a gallery, in continuity. Stockhausen succeeded in realizing this idea in the German pavilion within the 1970 EXPO in Osaka, when his compositions were emitted by means of multichannel system for rotation of sound in space, enabling circular and spiral sound movements. Among Stockhausen's pieces which could be characterized as the examples of spatial music are: Gesang der Jünglinge (1955-6), the achievement which was emitted by means of five groups, of fixed and mobile speakers; Gruppen (1955-7), the piece for three orchestras which encircle the audience in order to hear propagation of grouped sounds; Carre (1959-60), the composition for four orchestras treated in similar manner as in the previous piece, whereby the 
idea was that this achievement was played in the square shaped space; Music for a House (1968) - the composition planned to be played from $6 \mathrm{pm}$ till 10 $\mathrm{pm}$ in four rooms on two floors, whereby the audience has the possibility to visit theses rooms or to follow the acoustic happenings from other rooms while being in the fifth room. The idea about the unique building for presentation of music belonged also to the composer, the representative of music minimalism, La Monte Young. He conceived the concept Dream House (1962) as the space in which the musicians would live and in which music would be played in continuity for twenty-four hours. It concerns a light-sound installation which should enable the prolonged listening experience, acting as a specific space for presentation of pieces of music in integration with light installations of the visual artist Marian Zazeela. ${ }^{28}$ The idea of displacement of sound from the canon defined space lies in the basis of the research of Max Neuhaus, who is often talked about as a creator of the concept of sound installation and the term itself (1971). Such Neuhaus' position originated after his first percussionist career mainly dedicated to the repertory of the American experimental music, when he understood that the everyday sounds, namely the noise made the unavoidable 'decoration' of the concert space. For that reason, he questions: "Why limit listening to the concert hall? Instead of bringing these sounds into the hall, why not simply take the audience outside..." ${ }^{29}$ This questioning has led to Neuhaus' first sound installation, Drive in Music (1967), composed of radio transmitters which were positioned along half-a-mile long section of Buffalo, New York highway. During the 70s there followed similar Neuhaus'c achievements which problematized sound as spatial phenomenon: Water Whistle (1971) - the whistles produce the sound in the pool caused by the jet of pressurized water; Times Square (1977-92/2002-) - installation underneath the ventilation grille of the New York Times Square based on emitting one; Time Piece (1983) - installation based on recording the sounds of the Witney museum garden, which are then transformed by means of computer and emitted again in the same space in the new 'form' ${ }^{30}$ The issue of perception of sound in space/the space is dealt with by the Austrian artist and architect Bernhard Leitner, who since the beginning of the 70s has been working with sound as plastic, sculptural, architectural medium. i.e. as the means of space shaping. The work Sound Tube (1971), the installation based on the complex structure made of speakers through which the listener passes physically, is one of the first examples of Leitner's work within this field whereby he gives the advance sign of the key topics of his poetic: the relationship between the sound and the body during the act of perception, namely the role of the entire body in the process of perception; the relationship between sound and space and the possibility of space shaping by sound (in that context Leitner has been using 
the term „sound architecture”, since 1971). ${ }^{31}$ A remarkable example is the sound sculpture (TonRaum Skulptur) Sound Suit (1975) which installs the body as space of sound movement or the sound as medium of body production as space. The work consists of the suit with four built-in speakers by means of which it is possible to have a bodily/physical experience of the course of physical distribution of the emitted sound (it usually concerns the 'neutral' sounds which would not distract the attention and which would enable focusing on space). According to the same principle there originated the series of works Sound Chair (1975), namely various chairs with installed speakers which accentuate kinesthetic-haptic experience. The concept of „sound architecture" is possible to be perceived also in the example of the installation Sound Space (1984, Technical University, Berlin). It concerns a square shaped pass-through room whose high level of reverberation Leitner attenuates by installing perforated metal panels behind which is the acoustic absorbing material, which, like a membrane, retains the sound. Behind the panel there are forty-eight speakers installed which emit the sounds of trombone, trumpets, percussion... these sounds create various acoustic movements and in that way articulate the space..$^{32}$ Along with the term sound architecture, it should also be mentioned the concept of aural architecture which is discussed about by Barry Blesser, interpreting it as: "A real environment, such as an urban street, a concert hall, or a dense jungle, is sonically far more complex than a single wall. The composite of numerous surfaces, objects, and geometries in a complicated environment creates an aural architecture". ${ }^{33}$

Besides that sound can act as space borderline and its shape-forming factor, it can act as the medium of transfer of information from one to another location, namely as the means of documenting and creation of specific ambience, environment landscape. Such type of listening attentively, and then also creating sound 'notes' was formulated by Raymond Murray Schafer as soundscape (1969), and in the context of promoting the discipline of acoustic ecology (or soundscape studies), at the beginning of the $70 \mathrm{~s}$, which problematizes the relationship between the living beings and their environment by means of sound with an aim of indicating to the sound misbalance which may cause undesirable consequence in the environment. As the result of the analysis of the sound reality, namely the soundscape as ,any acoustic field of research", the first Schafer's audio recordings originated, which would serve as material for further study of the certain areas. ${ }^{34}$ The first recordings of the soundscapes Schafer made in Vancouver and released them under the title The Vancouver Soundscape (1972); then the project Soundscape of Canada followed, realized as ten-hours long radio program (1974); further 
on, followed the compiling of the recordings of soundscapes in the villages in Europe (in Sweden, Italy, Germany, France, Scotland), and the recordings were released under the title European Sound Diary, Five Village Soundscape, (1975). The German-Canadian female composer, radiophone artist and sound ecologist, Hildegard Westerkamp, was among the first to elaborate the idea of realization of soundscape composition. The piece A Walk through the City (1981) is singled out here, which is based on the sounds of Vancouver urban environment, in the original or altered form, whereby the continuum between the real and imaginary environment is established. The issue of the role of sounds of the environment in the artistic context has been dealt with also by Annea Lockwood since the $70 \mathrm{~s}$. She, actually, practices the principle of field recordings of sound and collecting, first, the sounds of nature (volcanoes, earthquakes, geysers, storms, ) and the animals, and special place is taken by recording the sounds of rivers (since 1966) and realization of sound maps of particular river flows - A Sound Map of the Hudson River (1982), A Sound Map of the Danube (2005), Sound Map of the Housatonic River (2010). It concerns the sound installations which were later on released in the form of compact discs, making it possible for the sound of the original environment to be interpreted in other environments, public and private ones, in a manner of music achievement.

The lack of alternative spaces for presentation of sound pieces has forced the composers and artists interested in sound to find new places for presentation, and since the world of the visual arts has always been more open and 'generous' towards the new tendencies, it became a particularly suitable filed for presentation of sound pieces. Wit emancipation of sound it was necessary, therefore, to emancipate preformation space as well, which would be flexible enough for various forms of sound tracking. Thus, since the late $50 \mathrm{~s}$, the course of sound emancipation was re-directed to the way which verified the hegemony of the visual and accentuating of until then neglected properties of the sound - along with the 'sensorial' properties, like volume, timbre, loudness, also that 'inaudible', such as duration and spatiality come to the prominence. Such sound treatment has particularly enabled the visual artists to confront the duration in yet, according to the established belief, timeless world of the visual arts, but also to additionally research the space (first that 'institutionalized', and thereafter the spaces beyond the institutional frames) i.e., spatiality as sound dimension, and, in the end, to engage other senses and open new horizons and spaces of artistic action: „the need to reintegrate arts in which sound, in its multifaceted forms, plays a significant role, has led the artists of this (XX, BS) century far beyond the traditional scope of painting art or sculpture, towards their own bodies and voices, towards the time, space and the environment.". ${ }^{35}$ 
On this trail, at the beginning of the $80 \mathrm{~s}$, there developed the concept which in the foreground places the relationship between sound and space. It concerns the sound art, the practice which describes, analyzes, plays and studies the condition and effect of sound in space. Sound art comprises border art practices in which the acoustic element controls the perception/reception, as well as the structure of the piece itself. Alan Licht exactly defines sound art in relation to the spatial dimension, singling out the three determinations of this concept: sound art can be understood as installation sound setting which is rather determined by space than by time and can be displayed in the manner of displaying visual art works; sound art can be a visual art work which also has the function of producing the sound, such as sound sculpture; sound art is possible to perceive as the practice of using sound in the field of visual arts for the purpose of enriching and extension of specific artistic aesthetics, which was otherwise defined by other means. ${ }^{36}$ That which connects all these three explanations is the image of the representation of sound as a phenomenon of nature and/or technology in the context defined by visual experience, namely exhibition space (i.e. the space which exists „behind the concert halls”), which would mean that sound art can be characterized as the practice which places the accent on sound (desirable and undesirable) and its environment. The musicologist Joanna Demers elaborates the musicological discourse on this phenomenon and develops the theory on sound as the transmitter of messages on space, place and location, namely on the sound as directional phenomenon representing the space borderlines ${ }^{37}$ It concerns the reciprocal exchange sound is positioned in certain space and it is affected by that space, and space acquires the 'form' exactly owing to sound. Sound thus becomes architectural material providing the building with certain dynamics. 
In many interpretations the term „concrete" has been replaced by the term "frozen". Therefore, in architectural/music discourse Schelling is known as the author of aphorisms on architectures as ,frozen music".

Friedrich Wilhelm Joseph von Schelling, The Philosophy of Art, trans. Douglas W. Scott (Minnesota: University of Minnesota Press, 1989), 165.

Denis Hollier, "Architectural Metaphors," in Architecture: Theory since 1968, ed. K. Michael Hays (Cambridge/London: The MIT press, 1998), 195.

Antonio Sant'Ellia, "Futurist Architecture," in Futurism: an anthology, eds. L. Rainey, C. Poggi, L. Wittman (New Haven/London: Yale University Press, 2009), 198-202.

Luigi Russolo, "The Art of Noises: A Futurist Manifesto," in Futurism: an anthology, eds. L. Rainey, C. Poggi, L. Wittman (New Haven/London: Yale University Press, 2009), 133-9.

This term relates to the pieces which originated in the period between 1917-23, which were first played between the acts of the plays of Max Jacob Ruffian toujours, truandjamais. During the play the audience was requested not to pay attention to the music, same as they do not pay attention to the chair or painting that is placed in the space of performing.

Le Corbusier, Der Modulor (Stuttgart: Deutsche Verlagsanstalt, 1998), 29.

Le Corbusier addressed this question in the text "L'espace indicible", 1946. See: Gascia Ouzounian, Sound Art and Spatial Practices: Situating Sound Installation Art Since 1958 (San Diego: University of California, 2008), 68-9.

See: Ianis Xenakis, Formalized music: thought and mathematics in composition (Hilsdale: Pendragon Press, 1992), 10-11.

See virtual reconstruction at page: http:/www.edu.vrmmp.it/vep/

Peter Cook, "Bloch City," Daidalos 1 (1985).

Peter Blundell Jones, "1989 august: Pare de la Villette by Bernard Tschumi Architects" (The Architectural Review, 2012, http://www.architectural-review.com/archive/1989-august-parc-de-la-villette-by-bernardtschumi-architects $/ 8630513$.article, accessed 28 . january 2013).

See interview: Daniel Libeskind, The Music of Architecture, http://www.dailymotion.com/video/xgkrpf daniel-libeskind-the-music-of-architecture_news (accessed 28. january 2013).

Similar standpoint was expressed also by Thodor Adomo exactly having in view Schoenberg's music as paradigm of modern music language. In that context Adorno states that modern music and architecture are connected by common characteristics: both are oriented towards expression and construction without ornaments. Adorno yet adds that the feeling of space in visual sphere corresponds to that which is musicality in acoustic sphere. Theodor W. Adorno, "Functionalism Today," in Rethinking Architecture: $A$ Reader in Cultural Theory, ed. Neil Leach (London: Routledge, 1997), 6.

Maria Anna Harley, Space and Spatialization in Contemporary Music: History and Analysis, Ideas and Implementations, PhD dissertation (Quebec: McGill University, 1994), 117.

See: Alan Licht, Sound Art: Beyond music, between categories (New York: Rizzoli, 2007), 43.

http:/www.furious.com/perfect/stockhauseninterview.html, accessed January 28, 2014.

According to: Maria Anna Harley, Space and Spatialization in Contemporary Music..., 157.

Brendon LaBelle, Background Noise: Perspectives on Sound Art (New York: Continuum, 2008), 73.

Max Neuhaus, "Listen", Sounds: documents on contemporary arts (London/Cambridge: Whitechapel Galery, The MIT press, 2011), 191.

Brendon LaBelle, Background Noise..., 155-8.

Brendon LaBelle, Background Noise..., 178.

Brendon LaBelle, Background Noise..., 179.

Barry Blesser \& Linda-Ruth Salter, Spaces Speak, Are You Listening? Experiencing aural architecture (Cambridge, London: The MIT Press, 2007), 2.

See: Raymond Murray Schafer, The Soundscape, Our Sonic Environment and the Tuning of the World (Rochester: Destiny Books, 1994).

William Furlong, Audio Arts: discourse and practice in contemporary art (New York: St. Martin Press, 1994), 67.

Alan Licht, Sound Art..., 17.

Joanna Teresa Demers, Listening Through the Noise: The Aesthetics of Experimental Electronic Music

(Oxford: Oxford University Press, 2010), 113-134. 
Adorno, Theodor W. "Funcionalism Today." In Rethinking Architecture: A Reader in Cultural Theory, edited by Neil Leach. London: Routledge, 1997.

Blesser, Barry \& Salter and Linda-Ruth. Spaces Speak, Are You Listening? Experiencing aural architecture. Cambridge, London: The MIT Press, 2007.

Blundell Jones, Peter. "1989 august: Pare de la Villette by Bernard Tschumi Architects." The Architectural Review 2012. http:/www.architectural-review.com/archive/1989-august-parc-de-la-villette-bybernard-tschumi-architects/86305 13.article (accessed January 28, 2014).

Bruhn, Siglind. The Musical Order of the World: Kepler, Hesse, Hindemith. Hillsdale: Pendragon Press, 2005.

Conway, Hazel and Roenisch, Rowan. Understanding the Architecture: an introduction to architecture and architectural history. London/New York: Routledge, 2005.

Cook, Peter. "Bloch City." Daidalos 1(1985).

Demers, Joanna Teresa. Listening Through the Noise: The Aesthetics of Experimental Electronic Music. Oxford: Oxford University Press, 2010.

Furlong, William. Audio Arts: discourse and practice in contemporary art. New York: St. Martin Press, 1994.

Hamilton, Andy. Aesthethics \& Music. London/New York: Continuum, 2008.

Harley, Maria Anna. Space and Spatialization in Contemporary Music: History and Analysis, Ideas and Implementations, PhD dissertation. Quebec: McGill University, 1994.

Hollier, Denis. "Architectural Metaphors", K. Michael Hays (ed.). Architecture: Theory since 1968. Cambridge/London: The MTT press, 1998.

LaBelle, Brendon. Background Noise: Perspectives on Sound Art. New York: Continuum, 2008.

Le Corbusier. Der Modulor. Stuttgart: Deutsche Verlagsanstalt, 1998.

Libeskind, Daniel. The Music of Architecture, http:/www.dailymotion.com/video/xgkrpf_daniellibeskind-the-music-of-architecture_news (accesse January 28, 2013).

Licht, Alan. Sound Art: Beyond music, between categories. New York: Rizzoli, 2007.

Neuhaus, Max. "Listen". Sounds: documents on contemporary arts. London/Cambridge: Whitechapel Galery, The MIT press, 2011.

Ouzounian, Gascia. Sound Art and Spatial Practices: Situating Sound Installation Art Since 1958. San Diego: University of California, 2008.

Pérez Gomez, Alberto. "The revelation of order: Perspective and architectural representation." In This is not arhitecture, edited by Kester Rattembury. London/New York: Routledge, 2002.

Russolo, Luigi. "The Art of Noises: A Futurist Manifesto." In Futurism: an anthology, edited by L. Rainey, C. Poggi, L. Wittman. New Haven/London: Yale University Press, 2009.

Sant'Ellia, Antonio. "Futurist Architecture." In Futurism: an anthology, edited by L. Rainey, C. Poggi, L. Wittman. New Haven/London: Yale University Press, 2009.

Schafer, Raymond Murray. The Soundscape, Our Sonic Environment and the Tuning of the World. Rochester: Destiny Books, 1994.

Schelling, Friedrich Wilhelm Joseph von. The Philosophy of Art, trans. Douglas W. Scott. Minnesota: University of Minnesota Press, 1989.

Šuvaković, Miško. Pojmovnik teorije umetnosti. Beograd: Orion Art.

Tatarkijevič, Vladislav. Istorija šest pojmova. Beograd: Nolit, 1978.

Vitruvius. The ten books of architecture. 2006. http://www.gutenberg.org/files/20239/20239-h/29239-h. htm\#Page_5 (accessed January 28, 2014).

Xenakis, Ianis. Formalized music: thought and mathematics in composition. Hilsdale: Pendragon Press, 1992. 


\section{BAUHAUS TEATAR - OSKAR ŠLEMEROV KONCEPT DIZAJNA U POKRETU}

\section{Sanela Nikolić}

Bauhaus Teatar je dobio svoju najpotpuniju formu kroz umetnički, pedagoški i teoretski rad Oskara Šlemera. Ključni problem za Šlemera je bio zakon kretanja ljudskog tela u prostoru. Njegova poetika je podrazumevala antinarativno $i$ antimimetičko pozorište $\mathrm{i}$ isto tako široko rasprostranjenu upotrebu scenskih figura uz živopisnu artikulaciju prostora kao svoje primarne namene. Ljudsko telo na sceni, pretvoreno $u$ artificijelnu figuru, je bilo univerzalni simbol ljudskog bića definisanog suprotnostima, koje postoji u geometrijski datom prostoru i odreduje ga metafizički. Upotreba termina ,igra" u većini naslova Šlemerovih komada je u skladu sa koncepcijom scenskog događaja kao scenske igre artificijelne figure u geometrijski određenom prostoru, Koncept dizajn-u pokretu, što znači organizacija scene sa specifično mehaničkim-koreografskim kretanjima i rad sa formom i bojom, određuje Šlemerovu scenu kao apsolutnu vizuelmu scenu. U okviru Bauhausa, scenski rad Oskara Šlemera je doprineo razumevanju pozorišnog događaja kao podjednako značajne oblasti umetničkog dela za dizajn celine prostora u kojoj je uspostavljen skald između čoveka, njegovog životnog procesa i okruženja u kome čovek postoji.

KLJUČNE REČI: BAUHAUS TEATAR,SSKAR ŠLEMER, KONCEPT DIZAJNA-U-POKRETU, VIZUELNA SCENA, MEHANIČKI/METAFIZIČKI, LJUDSKO TELO U PROSTORU, ARTIFICIJENA FIGURA, TRIADSKI BALET

\section{ARHITEKTURA KAO POLITIKA}

\section{Gabriela Świtek}

Ovaj rad prikazuje komentar o razmišljanju Žak Ransijera o arhitekturi kako je skicirano u Politici Estetike i postavljeno pored studije slučaja - 1. Izložba Arhitekture Narodne Poljske. Izložba koja je organizovana u eri Staljinizma (1953) i prikazana u Centralnom Birou za Umetničke Izložbe (današnja Zacheta (Zaheta) - Nacionalna Galerija umetnosti u Varšavi) je viđena kao maninifestacija "umetničkih režima" iz tog perioda i kao estetizacija arhitekture koja se obično smatra naj "političkijom" od svih (lepih) umetnosti. Izgleda da arhitektura nije glavno razmatranje Politike Estetike, većina prevodilaca i (Poljski) komentatori Ransijerovih filozofskih spisa skreću nam pažnju na značaj njegove estetike za odnosne aspekte savremene umetnosti u javnim prostorima. C̆lanak ima za cilja isticanje arhitektonkih trenutaka u Ransijerovon projektu estetike kao politike, on isto tako razrađuje nekoliko pojmova poiēsis/ mimēsis - kao što je rečeno od strane Ransijera - u odnosu na arhitektonsku teoriju i istoriju arhitektonskih izložbi.

ARHITEKTURA I MUZIKA/ZVUK:

TAČKE SUSRETANJA, UMREŽAVANJA, SADEJSTVA

\section{Biljana Srećković}

Ovaj tekst posvećen je sagledavanju odnosa izmedu muzike i arhitekture, odnosno diskursa koji interpretiraju, istražuju, vrednuju ove dve prakse u kontekstu njihovog medusobnog umrežavanja. U vezi sa tim, moguće je izdvojiti nekoliko problemskih uporišta koji će biti u fokusu ovog rada, a tiču se: istorije formiranja i evolucije diskursa o medusobnom odnosu ove dve prakse; modernističke, avangardističke $\mathrm{i}$ postmodernističke problematizacije muzike $\mathrm{i}$ arhitekture; teorije umetnika kao polja umrežavanja muzike $i$ arhitekture; interakcije muzike $i$ arhitekture na tehničkom i formalnom nivou; prostronosti zvuka, tj. prostiranja zvuka/muzike u prostoru i pojave novih umetničkih koncepata zasnovanih na ovom principu (sound architecture, aural arhitecture, sound art). 